\title{
CSAVARKÖTÉSEK OLDÁSI NYOMATÉKÁNAK VIZSGÁLATA
}

\section{ANALYSIS OF DISSOLVING TORQUE SCREW CONNECTIONS}

\author{
Szluk István ${ }^{1}$, Szigeti Ferenc ${ }^{2}$, Dezső Gergely ${ }^{3}$ \\ Nyirregyházi Egyetem, Müszaki és Agrártudományi Intézet, Müszaki Alapozó, Fizika \\ és Gépgyártástechnológiai Tanszék, Cím: 4400, Magyarország, Nyíregyháza, Kótaji \\ út 9-11, \\ ${ }^{1}$ szlukistvan@gmail.com \\ ${ }^{2}$ szigetif@nyf.hu \\ 3iezsog@nyf.hu
}

\begin{abstract}
Screw insurance with threadlocking is a really new technology. That's why we tested the treadlocking, and we wanted to know how strong the screw connection is. We tested four types of screw size (M6, M10, M16 and M20) 8.8 galvanized steel screws and 8 galvanized steel nuts, three types of threadlocking (Loctite 2400, Loctite 2700 and AJett 126) cleaned and raw screws and nuts. We did the test six times in the first session of curing ( 30 minutes, 1 hour, 3 hours, 1 day, 3 days and 1 week). After the testing we stated there are a lot of advantages of this technology.
\end{abstract}

Keywords: screw connections, screw insurance, threadlocking.

\section{Összefoglalás}

A menetrögzítővel történő csavarbiztosítás egy viszonylag újfajta technológia, ezért tartottuk fontosnak vizsgálni, hogy ezzel a módszerrel milyen erős kötések alakíthatóak ki. A vizsgálatok során négyféle menetméret esetén (M6, M10, M16, M20) 8.8-as horganyzott acél csavarokon vizsgáltunk három menetrögzítőt (Loctite 2400 és 2700, AJett 126) tisztított és tisztítás nélküli felületen. Az oldási nyomatékot a kikeményedési idő első szakaszában hat időpontban mértük (30 perc, 1 óra, 3 óra, 1 nap, 3 nap és 1 hét). A vizsgálatok alapján megállapítható, hogy igen kedvező tulajdonságai vannak ennek a technológiának.

Kulcsszavak: csavarkötések, csavarbiztositás, menetrögzitö.

\section{Bevezetés, célkitűzés}

A menetrögzítővel történő csavarbiztosítás egy viszonylag új technológia, mely- ben nem használnak különleges csavart, anyát vagy egyéb gépelemet (rugós alátét, kontra anya, bordázott peremü csavar, stb.). A menetrögzítős csavarbiztosítás előnyös, hiszen a mechanikai eszközök (biztosító 
lemez vagy a koronás anya) csak a kötés oldódását akadályozzák meg. A recézett peremü csavarok az önkioldást megakadályozzák, de viszonylag drágák, nagyobb méretű csavar szükséges, és az összefogni kívánt alkatrészek felülete sérül. A súrlódáson alapuló biztosító elemek növelik a kötés rugalmasságát, de a dinamikus terhelés ellen nem védik a csavarkötést.

A vizsgált menetrögzítők mindegyike egykomponensü, anaerob kötőanyag volt. $\mathrm{Az}$ anaerob menetrögzítö kikeményedése akkor indul meg, amikor az anyagot a környezeti levegőtől elzárjuk. A menetrögzítő kikeményedése során a menetrögzítő a menethez adhéziós, a ragasztómolekulák egymáshoz kohéziós kötéssel kapcsolódnak. A menetrögzítő használatának számos előnye van. Megbízható, hosszú élettartamú kötés alakítható ki, széleskörűen alkalmazható és eszközigénye kicsi.

A vizsgálatok célja annak vizsgálata, hogy a menetek tisztítása hogyan befolyásolja a kötés szilárdságát, hogyan változik az oldási nyomaték értéke a kikeményedés során, a különböző típusú menetrögzítő termékek alkalmazásakor hogyan alakul a kötési szilárdság, valamint a menetméret növelésével hogyan változik az oldáshoz szükséges nyomaték értéke.

\section{Kísérleti terv}

A kísérletekhez 8.8-as minőségü horganyzott acél csavarokat és 8-as horganyzott anyát használtunk. A menetméreteket úgy választottuk meg, hogy a menetemelkedés eltérő legyen, így a vizsgálatokhoz M6-os, M10-es, M16-os és M20-as csavarokat használtunk. A vizsgálatokhoz kétféle Loctite Health \& Safety menetrögzítőt (Loctite 2400 és 2700) valamint az AJett 126-os menetrögzítőjét használtuk. A kísérleteket elvégeztük Loctite SF 7063-as tisztító és zsírtalanító szerrel kezelt csavarokon valamint tisztítás nélkül kezeletlen csavarokon. A kikeményedés első szakaszában hat időpontban mértünk oldási nyomatékokat
30 perc, 1 óra, 3 óra, 1 nap, 3 nap és 1 hét elteltével.

\section{A kísérleti eredmények és érté- kelésük}

A kísérletek során állandó volt a menet típusa, a csavarok és anyák anyagminősége. Minden esetben normál métermenetet, 8.8as horganyzott acél csavarokat és 8-as horganyzott acél anyákat vizsgáltunk.

$\mathrm{Az}$ 1. ábrán látható, hogy a tisztított csavarokon végzett kísérletek esetén nagyobb oldási nyomatékok voltak mérhetőek, mint a kezeletlen csavarokon végzett kísérletek esetében. Ez abból adódik, hogy a menetrögzítök a tiszta felülethez jobban tapadnak, mint a kevésbé tiszta felülethez, így erősebb kötés alakítható ki.

Az oldási nyomatékok a kikeményedés első szakaszában jó közelítéssel logaritmikus jelleget mutatnak a Loctite menetrögzítő esetében. Ezt alátámasztja, hogy a mérési pontokra illesztett közelítő görbék korrelációs indexe a tisztítás nélküli csavarokon végzett kísérletek esetén 0,89 , míg a tisztított csavarokon végzett kísérletek esetén 0,93. Az AJett menetrögzítő kikeményedése is logaritmikus jellegü, de ez kevésbé illeszkedik pontosan. Ebben az esetben a tisztítás nélküli csavarokon végzett kísérletek korrelációs indexe 0,78 , míg a tisztított csavarokon végzett kísérletek indexe 0,87 .

A két nagy szilárdságú menetrögzítő (Loctite 2700 és az AJett 126) összehasonlítása során megfigyelhető, hogy rövidebb kikeményedési idő elteltével az AJett 126os menetrögzítő használatával lényegesen nagyobb volt a kötés szilárdága. Ez előnyös lehet nagysorozat és tömeggyártás esetén, ahol nem alkalmazható megfelelően a hoszszú kikeményedési idejü menetrögzítő. Rövid kikeményedési idő esetén a szállítás és raktározás során már megfelelő a kötés szilárdsága, ezért nem károsodik a kötés.

A különböző menetméreteken végzett kísérletek mérési pontjait a 2. ábra mutatja. Az ábrából megfigyelhető, hogy a menetméret növelésével nőtt az oldási nyomaté- 
kok értéke is. Ez azzal magyarázható, hogy a nagyobb menetméret esetén nagyobb a menetek felülete, így a menetrögzítő is nagyobb felületen kapcsolódik, tehát erősebb kötés alakítható ki.

A kísérletek során azt tapasztaltuk, hogy a kötés oldása után a csavarok és az anyák jelentősen felmelegedtek. Ez azzal magyarázható, hogy a kohéziós és adhéziós kötésekben tárolt energia bomlás után hőenergiává alakul. Oldás után a menetek közül a menetrögzítő nagyobb darabokban volt leválasztható a felületröl. A kötés bontása után megállapítható volt, hogy az adhéziós vagy a kohéziós kötés volt a gyengébb. Ha az adhézió volt a gyengébb, akkor a menet felületén kevés menetrögzítő maradt, és nagyobb darabokban maradt a kikeményedett menetrögzítő. Ha a kohézió volt a gyengébb, akkor mind az anya mind a csavar menetárkaiban megtalálható volt a menetrögzítő.

\section{Következtetések}

A kísérleti eredmények értékelése során megállapíthat volt, hogy az oldáshoz szükséges nyomaték a kikeményedési idő növelésével logaritmikus jelleg szerint növekszik. A logaritmikus jellegü közelítés megfelelőségét a korrelációs indexek magas értékei igazolják, az esetek többségében az illeszkedés szorossága 0,9 fölött volt.

A Loctite 2700-as menetrögzítővel nem értük el a termék adatlapjában megadott értékeket, de így is megfelelőnek tekinthetők a kísérleti eredmények. A Loctite 2400as típusú menetrügzítővel végzett kísérletek már nem voltak ennyire eredményesek. A két menetrögzítö összehasonlításából egyértelmüen kiderült, hogy a Loctite 2700 -as menetrögzítővel érhető el nagyobb kötésszilárdság, hiszen míg a Loctite 2400 -as közepes szilárdságú addig a Loctite 2700 -as nagy szilárdságú menetrögzítő.

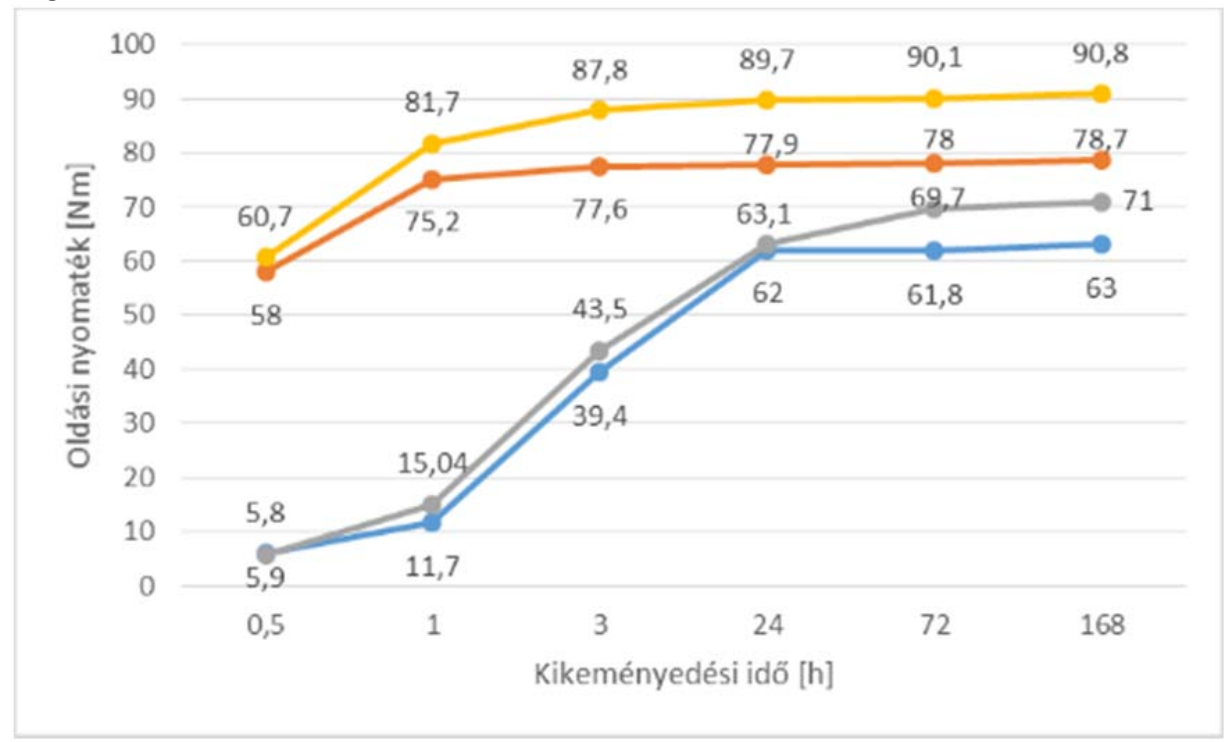

1. ábra. A Loctite 2700 és az AJett 126 összehasonlitása M16-os csavarméreten (narancssárga: AJett 126 tisztitott csavarokon, piros: AJett 126 kezeletlen csavarokon, szürke: Loctite 2700 tisztított csavarokon, kék: Loctite 2700 kezeletlen csavarokon) 


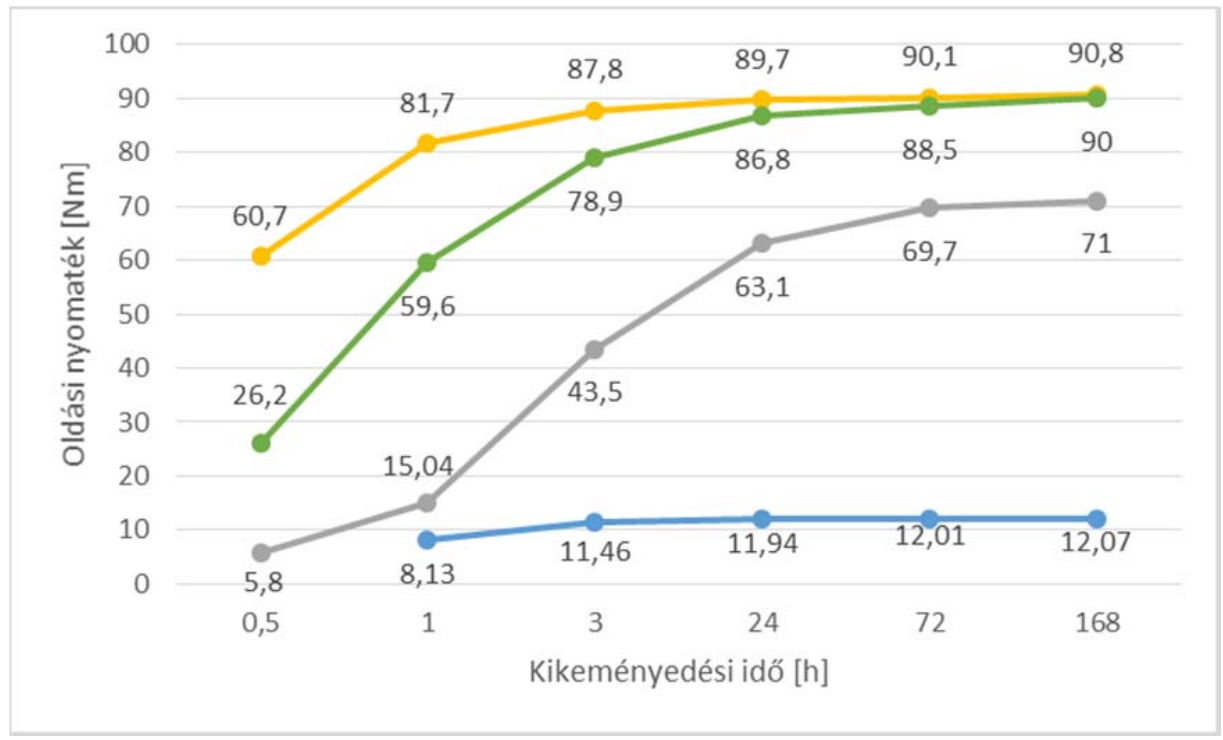

2. ábra. Az oldási nyomaték értékei különbözö menetméretnél tisztitott csavarokon (narancssárga: AJett 126, M16, zöld: Loctite 2700 M20, szürke: Loctite 2700 M16, kék: Loctite 2700 M10)

Bebizonyosodott, hogy a menetméret növelésével nő az oldáshoz szükséges nyomaték is. Ennek az az oka, hogy nagyobb menetméret esetén nagyobb a menetek felülete, így a menetrögzítő is nagyobb felületen kapcsolódik, ezáltal nagyobb a kötés szilárdsága. Ezt a megállapítást a Loctite 2700-as menetrögzítő eredményei szemléltetik jól, hiszen ezzel a menetrögzítővel három menetméreten is volt mérhető eredmény.

M16-os méreten vizsgáltam az AJett 126-os menetrögzítőt is. Mivel ez is nagy szilárdságú menetrögzítő, így a Loctite 2700-assal összehasonlítóak az eredmények. A két nagy szilárdságú menetrögzítő közül az AJett menetrögzítővel biztosított csavarokon volt mérhető nagyobb oldási nyomaték.

Az AJett menetrögzítő rövid kikeményedési ideje előnyösebb, hiszen így a szerelés befejezéséig annyira kikeményedik a menetrögzítő, hogy a tárolás és szállítás során nem gyengül a kötés. A Loctite 2700 előnye, hogy környezetbarát, ezáltal a környezetre és a dolgozóra sem jelent veszélyt. Ennek az az ára, hogy inaktív felületeken kevésbé gyors a kikeményedés valamint az enyhén szennyezett felületeken ez a menetrögzítő kevésbé hatékony.

\section{Szakirodalmi hivatkozások}

[1] JANIK J.: Menet és csavartáblázatok, Müszaki Könyvkiadó, Budapest. 1974

[2] HENKEL: Csavarrögzítés Felhasználási útmutató, Loctite, Budapest, 2008

[3] HENKEL: Worldwide design handbook, Loctite, München, 1998

[4] Loctite 2400 Data Sheet: http://tds.loctite.com/tds5/docs/2400-EN.PDF

[5] Loctite 2700 Data Sheet: http://tds.loctite.com/tds5/docs/2700-EN.PDF

[6] AJett 126 Data Sheet: http://www.ajett.com/AJett-126-TDS.pdf 